\title{
The influence of knowledge management on lecturer performance through job satisfaction
}

\author{
M. Ali Hasballah ${ }^{\mathbf{a}^{*}}$
}

${ }^{a}$ Iskandarmuda University, Banda Aceh, Indonesia

\begin{tabular}{l}
\hline C H R O N I C L E \\
\hline Article history: \\
Received: July 20, 2020 \\
Received in revised format: \\
September 102020 \\
Accepted: October 1, 2020 \\
Available online: \\
October 1, 2020 \\
\hline Keywords: \\
Knowledge Management \\
Job Satisfaction \\
Lecturer Performance
\end{tabular}

\section{A B S T R A C T}

This study aims to analyze the effect of knowledge management on job satisfaction, analyze the effect of knowledge management on lecturer performance, analyze the effect of job satisfaction on lecturer performance, and analyze the effect of knowledge management on lecturer performance through job satisfaction. The number of samples in this study were 55 respondents. The analysis technique uses path analysis. The results of the analysis show that knowledge management had a significant effect on job satisfaction. Knowledge management had a significant effect on lecturer performance. Job satisfaction had a significant effect on lecturer performance. Knowledge management had a significant effect on lecturer performance through job satisfaction.

Lecturer Performance

\section{Introduction}

In this era of globalization, knowledge management is one of the things that can be offered in addition to human resources and other physical resources possessed by an organization. The concept of knowledge as an asset of an organization can be used as a distinguishing feature of an organization. In order for these assets to become a resource in organizational development, knowledge must be organized in an orderly manner. This organizing is done with knowledge management. Knowledge management is divided into two categories, namely tacit knowledge and explicit knowledge. Tacit knowledge is knowledge that individuals get from daily experience, which is basically difficult to duplicate and teach to others (Nonaka, 1994). The key to tacit knowledge is experience. Therefore, tacit knowledge is personal, which makes it difficult to communicate and formalize (Nonaka, 1994). Meanwhile, explicit knowledge is knowledge that can be transferred to other individuals so that in practice it is easy to describe in documents, training, etc. where the authors categorize it into the form of work procedures and technology (Bohn quoted from Alavi et al., 2001). Job satisfaction has a role for organizations, organizations to support human resources. One of the strategies adopted by the organization is to provide activities that are able to meet the knowledge needs of human resources. Knowledge management is one of the activities that have been widely applied in organizations. The existence of knowledge management activities is expected to be able to meet job satisfaction in the organization. Knowledge management is carried out to meet satisfaction. Knowledge management is important in organization, according to Mattew (2010) knowledge management is a process that helps organizations identify, select, organize, disseminate and transfer important information and experiences that are a major part of the organization. Jadidi et al. (2013) found that knowledge management has an effect on job satisfaction. In order to produce good lecturer performance in the current era of knowledge, universities need management or management that can treat all lecturers' knowledge as a university asset. Knowledge management itself is applied by universities to be a solution in solving higher education problems,

* Corresponding author.

E-mail address: alihasballah20@gmail.com (M. A. Hasballah) 
with the final result achieving the expected goals and vision, which is measured by three components, namely people, process and technology (Bhojaraju, 2005). The main components in knowledge management help the organization achieve the goals and visions of higher education. This is related to the performance of lecturers, where lecturers are the main driving force of a university, so that when the lecturers' performance is good, the organizational performance is also good and vice versa, in performance there is also knowledge as an ability that is fulfilled. Therefore, universities need to know the extent to which knowledge management plays a role in improving lecturer performance. According to Bernardin and Russel (2003), lecturer performance is measured through five criteria for lecturer assessment, namely: quality, quantity, timeliness, need for supervision, and interpersonal impact. Falah and Prasetya (2017) found that knowledge management has an effect on lecturer performance.

\section{Literature review}

\subsection{Knowledge Management}

Mattew (2010) defines knowledge management as a process that helps organizations identify, select, organize, disseminate and transfer important information and experiences that are a major part of the organization. Furthermore, Tiwana (2000: 5) defines Knowledge Management as an organized management of knowledge to create business value and generate competitive advantages. Darroch (2003) argues that knowledge management is a function that serves, identifies and managesorganizational knowledge for long-term benefit. Furthermore, Tiwana (2000: 5) defines Knowledge Management as an organized management of knowledge to create business value and generate competitive advantages.

\subsection{Job satisfaction}

Robbins and Judge (2009) defined job satisfaction as a general attitude of individuals towards their work where in that job a person is required to interact with colleagues and superiors, follow the rules and policies of the organization to meet performance standards. Furthermore, according to Luthan (2006: 243) “job satisfaction is the result of employees' perceptions of how well their work provides things that are considered important. In general, in the field of organizational behavior, job satisfaction is the most important and frequently studied attitude". Meanwhile, according to Sutrisno (2011: 77) "employee job satisfaction is an important issue that is considered in relation to employee work productivity and dissatisfaction is often associated with a high level of job demands and complaints".

\subsection{Performance}

Performance is the result of work in quality and quantity achieved by an employee in carrying out his function in accordance with the responsibilities assigned to him. Basically, performance is something that is individual, because each employee has different levels of abilities. In addition, employee performance is also influenced by the level of education, initiative, work experience, and employee motivation. According to Sembiring (2012: 81), performance is a description of the level of achievement of an activity, policy, program in realizing the vision, mission and goals of the organization. According to Handoko (2001: 21), performance is a measure of the success of employees. Performance is conceptualized as a person's behavior in setting work goals, achieving work targets, working methods and personal characteristics. Employee performance is the result of work in quality and quantity achieved by an employee in carrying out his duties in accordance with the responsibilities assigned to him, (Mangkunegara, 2005: 9). As'ad (2003: 35) argues that performance is closely related to the attitude of employees towards their work, work situations, cooperation between leaders and employees, and among employees. Then according to Sulistyani (2003: 223) a person's performance is a combination of abilities, efforts and opportunities that can be assessed from the results of his work. Furthermore, Hasibuan (2001: 34) argues that performance (work performance) is a result of work achieved by a person in carrying out the tasks assigned to him based on skill, experience and seriousness and time. Performance can be viewed as a process of how work takes place to achieve work results. But the results of the work itself also show performance (Wibowo, 2009).

\subsection{Hypothesis}

H1 : Knowledge management affects job satisfaction.

$\mathrm{H} 2$ : Knowledge management has an effect on lecturer performance.

H3 : Job satisfaction affects lecturer performance.

H4 : Knowledge management affects lecturer performance through job satisfaction.

\section{Methodology}

\subsection{Research design}

Based on the objectives of this study, the research design was a causality research design. According to Sanusi (2014: 14), causality design is a research design to examine the possibility of a cause-and-effect relationship between variables. In this 
design, generally the causal relationship (that) can be predicted by the researcher, so that the researcher can state the classification of the causal variable, intermediate variable, and the dependent variable. The approach used in this research is a quantitative approach, the process begins with the preparation of a theoretical model and analysis as a basis for asking temporary questions (hypothesis), then continues with the operationalization of the concept, to the conclusion as a research finding.

\subsection{Population, Samples and Sampling Techniques}

Population is the totality of all possible values, both counting results and quantitative and qualitative measurements rather than certain characteristics regarding a complete and clear group of objects (Sudjana, 2008: 164). Another definition states that population is a group of objects, whether humans, symptoms, test scores, objects or events (Arikunto, 2009). The population in this study were all 122 lecturers at the Iskandar Muda University. The number of samples in this study is calculated using the Slovin formula, in order to obtain a total sample of 55 respondents.

\subsection{Operational Definition of Variables}

\section{a. Knowledge management}

Knowledge management is information that changes a person and becomes the basis for acting more effectively than previous actions. Knowledge management indicators are as follows: People, Process and Technology.

\section{b. Job satisfaction}

Job satisfaction is an attitude that workers have about job work. The indicators used are as follows: Mentally challenging work, appropriate rewards, supportive working conditions, supportive co-workers, and suitability between personality and work

\section{c. Lecturer Performance}

Performance is the employee's performance in carrying out tasks in accordance with their main duties and responsibilities in a job, as measured by the following indicators: Quality, Quantity, Timeliness, Effectiveness and Relationships between Individuals.

\subsection{Data analysis method}

The analysis technique used in this research is path analysis. As for analyzing the data in this study, using SPSS (Statistical Program for Social Science) 20 For Windows as the software. The researcher's consideration in using this software is that the flexibility of the SPSS 20 for windows software causes various kinds of data analysis to be handled easily and well.

\section{Analysis and discussion}

\section{- $\quad$ The Influence of Knowledge Management on Job Satisfaction}

Here we test the effect of knowledge management on job satisfaction directly, and the magnitude of the direct effect by using a simple linear regression method. As for the results the calculations are presented in Table 1 below.

\section{Table 1}

The Influence of Knowledge Management on Job Satisfaction

\begin{tabular}{lcc}
\hline \multicolumn{1}{c}{ Variable } & Coefficient Regression & Value of $\mathrm{t}$ \\
\hline Knowledge management & 0.801 & 9.724 \\
\hline Variable bound: Satisfaction $\mathrm{R}=0.801 \mathrm{R}$ square $\left(\mathrm{R}^{2}\right)=0.641$ & & 0.000 \\
\hline Source: Primary data processed, 2020. & &
\end{tabular}

The influence of knowledge management on job satisfaction is significant at the level $\alpha$ amounting to $5 \%$ with a $p$ value of 0,000 , the regression coefficient is 0.801 . The meaning knowledge management effect on satisfaction, the better knowledge management will increase satisfaction. The coefficient of determination is shown by the model summary, where the value of $\mathrm{R}^{2}$ is 0.641 or $51.9 \%$ and the magnitude of the influence of other variables, namely $48.1 \%$. This shows that the contribution of the influence of the knowledge management against job satisfaction is equal to $51.9 \%$ while $48.1 \%$ of the job satisfaction is influenced by other variables. 
To determine the effect of knowledge management and job satisfaction on lecturer's performance directly, we use multiple linear regression and Table 2 shows the summary of the results.

Table 2

The Influence of Knowledge Management and Job Satisfaction on Lecturer Performance

\begin{tabular}{lcc}
\multicolumn{1}{c}{ Variable } & Coefficient Regression & Value of t \\
\hline Knowledge management & 0.640 & 6.653 \\
Satisfaction & 0.312 & 3.245 \\
\hline Variable bound : Lecturer performance & & 0.000 \\
\hline
\end{tabular}

The effect of knowledge management on lecturer performance is significant at the level $\alpha$ amounting to $5 \%$ with a p value of 0.000 , a regression coefficient of 0.640 . This means that knowledge management has positive effect on lecturer performance, better knowledge management will improve lecturer performance. Influence of job satisfaction to lecturer performance is significant at the level $\alpha$ amounting to $5 \%$ with a $\mathrm{p}$ value of 0.002 and the regression coefficient of 0.312 . This means job satisfaction influences on lecturer performance and better job satisfaction will improve lecturer performance. The significance of the coefficient of determination is indicated where the R-Square value is 0.827 . This shows that the contribution of the influence of variables knowledge management and job satisfaction against lecturer performance is equal to 83 .

\section{- Research Variable Path Analysis}

The results of the path analysis are presented in Table 3 as follows.

Table 3

Summary of Results of Analysis of Direct, Indirect, and effect of Total from Path Analysis

\begin{tabular}{lcc}
\multicolumn{1}{c}{ Variable } & Direct Effect & Indirect Effect \\
\hline Knowledge management $\rightarrow$ Job satisfaction & 0.801 & Total Effect \\
Knowledge management $\rightarrow$ Lecturer performance & 0.640 & - \\
Job satisfaction $\rightarrow$ Lecturer performance & 0.312 & - \\
Knowledge management $\rightarrow$ Job satisfaction $\rightarrow$ Lecturer performance & 0.640 & - \\
\hline
\end{tabular}

Source: Primary data processed, 2020.

Based on Table 3, it appears that the effect of the total knowledge management variable on lecturer performance (0.890) is greater than the direct effect (0.640). These results indicate that job satisfaction is an intervening variable in the influence of knowledge management on lecturer performance, because the total value is greater than the direct effect.

The results of calculations using the online Sobel Test can be seen in the following table.

Table 4

Online Sobel Test Results Influence of Knowledge Management on Lecturer Performance through Job Satisfaction

\begin{tabular}{lll}
\hline Sobel test & 3.07812892 & 0.00208305 \\
\hline Aroian & 3.06358689 & 0.002187701 \\
Goodman test & 3.09288002 & 0.00198224 \\
\hline
\end{tabular}

Source: Data processed, 2020

Based on the online Sobel test results, we understand that the t-statistic value of 3.102 is greater than the t-table value of 2.000 $(3.102>2.000)$ and the $p$-value of 0.002 is smaller than the significance value of $0.05(0.002<0.05)$. Thus, it can be concluded that job satisfaction mediates the effect of knowledge management on lecturer performance. Based on the results of the path analysis, the path model is presented in Fig. 1 below.

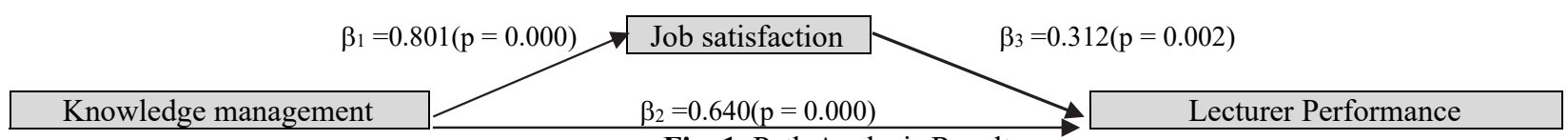

Fig. 1. Path Analysis Results

\section{- Hypothesis test}

- Hypothesis testing First

According to Table 1 , the knowledge management beta coefficient value is statistically meaningful $\left(\beta_{1}=0.801, \mathrm{p}\right.$-value $=$ 0.000 ) when the level of significance is one percent. Thus, the first hypothesis is confirmed knowledge management influences positively on job satisfaction. 
- $\quad$ Testing the second hypothesis

Based on Table 2, the knowledge management beta coefficient value is statistically meaningful $\left(\beta_{2}=0.653, p\right.$-value $\left.=0.000\right)$, which means that knowledge management has a significant effect on lecturer performance. Thus, the second hypothesis of the survey is confirmed.

- $\quad$ Testing the third hypothesis

According to Table 2, the beta coefficient value of job satisfaction is equal to 0.312 with the $t$ value of 3.245 and the $p$ value of 0.002, which means that job satisfaction has a significant effect on lecturer performance. Thus, the third hypothesis which states that job satisfaction has an effect on lecturer performance is confirmed.

- $\quad$ Fourth Hypothesis Test

Based on Table 3 and Table 4, the results of the analysis show that job satisfaction has maintained an intervening role on the effect of knowledge management on lecturer performance, since the total value (0.890) is greater than the direct effect $(0.640)$ and the t-statistic value of 3.078 is greater than the t-table value of $2,000(3.102>2,000)$ and the p-value of 0.002 is smaller than the significance value of $0.05(0.002<0.05)$, and the hypothesis is confirmed.

\section{- Discussion}

When knowledge management influences on job satisfaction, it means that better application of knowledge management can increase job satisfaction. Knowledge management can be a solution in solving organizational problems, with the end result achieving the expected goals and visionan. Therefore, the application of knowledge management plays an important role in increasing job satisfaction. As Mattew (2010) argues, knowledge management as a process may help organizations identify, select, organize, disseminate and transfer important information and experiences that are a major part of the organization. Information and knowledge are often used interchangeably even though there are differences in them. Knowledge comes from the flow of information since information provides a new view to interpret each event or object. Information is the medium or material needed to acquire, build and develop knowledge. The results of this study is consistent Jadidi et al. (2013) which states that knowledge management affects job satisfaction.

Knowledge management effects on lecturer performance, which means that increasing knowledge management can improve lecturer performance. Knowledge management not only improves performance, but also gains shared knowledge. With the existence of shared knowledge, lecturers have broader insights not only about their field of work but also regarding problems that exist on a corporate scale. For the organization itself, the incorporation of individual knowledge from lecturers will obtain a knowledge base of the organization. Knowledge management is a process for finding, storing, and sharing knowledge (expertise, skills, experiences, and networks) that are owned by lecturers in the organization for the organization. The application of knowledge management can have a positive impact on organizational business processes, either directly or indirectly, such as saving time and costs, increasing knowledge assets, and adaptability. The results of this study are supported by Falah and Prasetya (2017) who state that knowledge management affects lecturer performance.

Job satisfaction has an effect on lecturer performance, which means that higher level of job satisfaction can increase the lecturer's performance. Job satisfaction reflects the attitude of the lecturer on his job, which is seen in the positive attitude of the lecturer towards work and everything that is faced at the place where the lecturer works. Job satisfaction is a form of pleasure for what the lecturer has done, but job satisfaction is subjective. Satisfaction between one individual and another tends to be different, because each individual has his/her own satisfaction criteria in measuring the level of life satisfaction, but the satisfaction of lecturers at work can be seen from the lecturers' performance. Lecturers who are satisfied at work always come on time, which means that the lecturer appreciates the work and responsibility for the tasks that must be accomplished. When lecturer is happy in doing his/her job and do not complain about assignments and jobs, he is always able to accept new and difficult jobs gracefully and have a harmonious relationship with other lecturers and superiors. The results of this study support Kianto et al. (2016) and Loan (2020) who state that job satisfaction has an effect on performance.

Job satisfaction mediates the effect of knowledge management on lecturer performance. This shows that knowledge management can improve lecturer performance if lecturers are satisfied with their work. Knowledge management has an important role in increasing employee job satisfaction. The aim of the organization is to apply knowledge management as a way to achieve prosperity at work and increase job satisfaction which has an impact on improving lecturer performance.

\section{Conclusion and recommendations}

\subsection{Conclusion}

Knowledge management has a significant effect on job satisfaction, which means that higher knowledge management can increase job satisfaction. Knowledge management has a significant effect on lecturer performance, which means that better 
knowledge management can improve lecturer performance. Job satisfaction has a significant effect on lecturer performance, which means that higher level of job satisfaction can improve lecturer's performance. Knowledge management has a significant effect on lecturer's performance through job satisfaction.

\subsection{Recommendations}

Knowledge management in organizations is already running well, but organizations need to further improve so that it would not experience a decline in knowledge management activities. Organizations need to be supported by providing mentoring activities so that lecturers' ideas can be accommodated. Organizations also need to provide rewards so that lecturers can contribute more actively.

\section{References}

Alavi, M., \& Leidner, D.E. (2001). Knowledge management and knowledge management systems: Conceptual foundations and research issues. MIS Quarterly, 25(1), 107-136.

Arikunto, S. (2009). Prosedur Penelitian: Suatu Pendekatan Praktek. Jakarta: Rineka Cipta.

As'ad. (2003). Kepemimpinan Efektif Dalam Perusahaan. Ed.2. Yogyakarta: Liberty.

Bernardin, H.J., \& Russel, J.E. (2003). Human Resource Management. New Jersey: International Editions Upper Saddle River, Prentice Hall.

Bhojaraju, G. (2005). Knowledge management: Why do we need it for corporates. Malaysian Journal of Library \& Information Science, 10(2), 183-190.

Darroch, J. (2003). Developing a measure of knowledge management behaviours and practices. Journal of Knowledge Management, 7(5), 41-54.

Falah, A. S. N \& Prasetya, A. (2017). Pengaruh Knowledge Management Terhadap Kinerja Karyawan dan Kinerja Perusahaan (Studi Pada Karyawan Pt Semen Indonesia Persero Tbk). Jurnal Administrasi Bisnis, 50(4), 192-198.

Handoko, T. H. (2001). Manajemen Personalia dan Sumberdaya Manusia, Edisi Kedua. Yogyakarta: BPFE.

Jadidi, R., Ehsanifar, M \& Moshtaghi, S. (2013). A study on the effect of knowledge management on job satisfaction: A Case study of texture industry. Management Science Letters, 3(12), 3037-3042.

Kianto, A., Vanhala, M., \& Heilmann, P. (2016). The impact of knowledge management on job satisfaction. Journal of Knowledge Management, 20(4), 621-636.

Loan, L. (2020). The influence of organizational commitment on employees' job performance: The mediating role of job satisfaction. Management Science Letters, 10(14), 3307-3312.

Luthans, F. (2006). Organizational Behavior. International Edition. McGraw Hill.

Mangkunegara, A.A. A. P. (2005). Manajemen Sumber daya Manusia Perusahaan. Bandung : PT Remaja Rosdakarya

Mattew, V. (2010). Service delivery through knowledge management in higher education. Journal of Knowledge Practice, 11.

Nonaka, I. (1994). A dynamic theory of organizational knowledge creation. Organization Science, 5(1), 14-37.

Robbins, S. P. \& Judge, T. A. (2009). Organizational Behavior. 13 ThreeEdition, USA: Pearson International Edition, Prentice -Hall.

Sanusi, A. (2014). Metodologi Penelitian Bisnis. Cetakan Kelima. Penerbit Salemba Empat. Jakarta.

Sembiring, M. (2012). Budaya dan Kinerja Organisasi. Bandung: Fokusmedia.

Sudjana. (2002). Metoda Statistika. Bandung: Tarsito.

Sulistiyani, A. T. (2003). Manajemen dan Sumber Daya Manusia : Konsep Teori dan Pengembangan Dalam Konteks Organisasi Publik. Yogyakarta : Graha Ilmu.

Sutrisno, E. (2011). Manajemen Sumber Daya Manusia. Penerbit: Jakarta, Kencana.

Tiwana, A. (2000). The Knowledge Management Toolkit: Practical Techniques for Building A Knowledge Management System. New Jersey: Pretince Hall PTR.

Wibowo. (2009). Manajemen Kinerja. PT. Raja Grafindo Parsada: Jakarta.

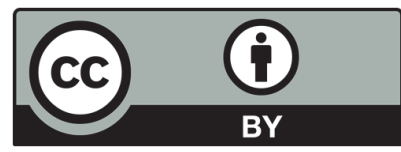

(C) 2020 by the authors; licensee Growing Science, Canada. This is an open access article distributed under the terms and conditions of the Creative Commons Attribution (CC-BY) license (http://creativecommons.org/licenses/by/4.0/). 